\title{
POLA BAKTERI AEROB YANG BERPOTENSI MENYEBABKAN INFEKSI NOSOKOMIAL DI RUANG ICU BLU RSUP PROF. DR. R. D. KANDOU MANADO
}

\author{
${ }^{1}$ Prilly V. Londok \\ ${ }^{2}$ Heriyannis Homenta \\ ${ }^{3}$ Velma Buntuan
}

\author{
${ }^{1}$ Kandidat Skripsi Fakultas Kedokteran Universitas Sam Ratulangi Manado \\ ${ }^{2}$ Bagian Mikrobiologi Fakultas Kedokteran Universitas Sam Ratulangi Manado \\ Email: plondok@yahoo.com
}

\begin{abstract}
Infections that can be found during the treatment in the ICU are due to contamination of pathogenic bacteria as the source of nosocomial infections. This nosocomial infections appear and show symptoms in patients treated or after being treated in the hospital. This study aimed to determine the sources and patterns of aerobic bacteria that could potentially cause nosocomial infections: in the walls, floors, medical equipment, and in the ambient air of ICU Room, Prof. Dr. R. D. Kandou Hospital, Manado. This was a descriptive study designed with a prospective approach. Samples were bacteria in the walls, floors, medical equipment, and the ambient air of the ICU Room. The results showed that of the 27 samples taken, there were 24 bacteria found: Enterobacter agglomeranse (25\%), Bacillus subtilis (25\%), Enterobacter cloacae (16.7\%), Staphylococcus sp. (8.4\%), Gram-negative cocci (16.4\%), Serratia rubidaea (4.1\%), and Klebsiella pneumonia (4.1\%).
\end{abstract}

Keywords: ICU, nosocomial infections, patterns of aerobic bacteria

\begin{abstract}
Abstrak: Infeksi yang dapat ditemukan pada perawatan di ICU karena terkontaminasi dengan sumber bakteri patogen yaitu infeksi nosokomial. Infeksi nosokomial adalah infeksi yang muncul dan menunjukkan gejala selama pasien dirawat atau setelah dirawat di rumah sakit. Penelitian ini bertujuan untuk mengetahui sumber dan pola bakteri aerob yang berpotensi menyebabkan infeksi nosokomial di dinding, lantai, peralatan medis, dan udara di ruang ICU BLU RSUP Prof. dr. R. D. Kandou Manado. Desain penelitian ini bersifat deskriptif dengan pendekatan prospektif. Sampel penelitian ialah bakteri pada dinding, lantai, peralatan medis, dan udara di ruang ICU BLU RSUP Prof. Dr. R. D. Kandou Manado. Hasil penelitian memperlihatkan dari 27 sampel yang diambil, terdapat 24 bakteri yaitu Enterobacter agglomerans (25\%), Bacillus subtilis (25\%), Enterobacter cloacae (16,7\%), Staphylococcus sp. (8,4\%), Kokus Gram negatif (16,4\%), Serratia rubidaea (4,1\%), dan Klebsiella pneumonia $(4,1 \%)$.
\end{abstract}

Kata kunci: ICU, infeksi nosokomial, pola bakteri aerob

Rumah sakit merupakan bagian integral organisasi pelayanan medis yang bertugas memberikan layanan kesehatan baik preventif maupun kuratif kepada masyarakat sekitar beserta lingkungannya. Kegiatan tersebut menimbulkan dampak 
positif dan negatif. Dampak positif ialah meningkatnya derajat kesehatan masyarakat, sedangkan dampak negatifnya ialah agen penyakit yang dibawa oleh penderita dari luar ke rumah sakit atau pengunjung yang berstatus karier. Kuman penyakit ini dapat hidup dan berkembang di lingkungan rumah sakit, seperti udara, air, lantai, makanan, dan peralatan medis. ${ }^{1}$

Rumah sakit juga sebagai institusi yang memberikan pelayanan medis untuk semua jenis penyakit termasuk infeksi. Penyakit infeksi merupakan penyebab utama tingginya angka kesakitan dan kematian di dunia. ${ }^{1}$ Pasien-pasien yang dirawat di Intensive Care Unit (ICU) mempunyai pertahanan tubuh yang menurun, monitoring keadaan secara invasif, terpapar dengan berbagai jenis antibiotik dan terjadi kolonisasi oleh bakteri resisten mengakibatkan pasien yang dirawat mempunyai potensi lebih besar mengalami infeksi. ${ }^{2}$

Infeksi yang dapat ditemukan pada perawatan di ICU karena terkontaminasi dengan sumber bakteri patogen yaitu infeksi nosokomial. Infeksi nosokomial adalah infeksi yang muncul dan menunjukkan gejala selama pasien dirawat atau setelah dirawat di rumah sakit. ${ }^{3}$

Infeksi nosokomial banyak terjadi di seluruh dunia dengan kejadian terbanyak di negara yang sedang berkembang karena penyakit infeksi masih menjadi penyebab utama kesakitan dan kematian. ${ }^{4}$

Penelitian yang dilakukan oleh WHO menunjukkan infeksi nosokomial sekitar 8,7\% dari 55 rumah sakit dari 14 negara yang berada di Eropa, Timur tengah, Asia Tenggara dan Asia Pasifik, dengan jumlah infeksi nosokomial di Asia Tenggara sebanyak 10\%. ${ }^{5}$ Sementara di Amerika Serikat ada sekitar 20.000 kematian setiap tahun akibat infeksi nosokomial. ${ }^{2}$

Di Indonesia tahun 2006 diperoleh angka kejadian infeksi nosokomial di Provinsi Lampung 4,3\%, Jambi 2,8\%, Jawa Barat 2,2\%, DKI Jakarta 0,9\%, Yogyakarta 0,8\%, dan Jawa Tengah 0,5\%. ${ }^{6}$

Berdasarkan hasil temuan diatas, dan mengingat sampai saat ini belum ada penelitian tentang pola kuman yang berpotensi menyebabkan infeksi nosokomial di ICU BLU RSUP Prof. Dr. R. D. Kandou Manado, maka penulis tertarik melakukan penelitian ini.

\section{METODE PENELITIAN}

Penelitian ini dibuat dengan menggunakan metode deskriptif dengan pendekatan studi prospektif. Penelitian ini dilakukan pada bulan November 2014 Januari 2015. Terdapat 27 sampel dalam penelitian ini yang berasal dari dinding, lantai, peralatan medis, dan udara di ruang ICU BLU RSUP Prof. dr. R. D. Kandou Manado. Pengelolaan sampel dilakukan di Laboratorium Mikrobiologi Fakultas Kedokteran Universitas Sam Ratulangi Manado dengan pewarnaan Gram dan dilanjutkan dengan uji biokimia.

\section{HASIL PENELITIAN}

Berdasarkan penelitian yang dilakukan selama bulan November 2014 Januari 2015 telah dilakukan pengambilan sampel di ruang ICU BLU RSUP Prof. Dr. R. D. Kandou Manado.

Pada Tabel 1 dapat dilihat sampel berjumlah 27 yang diambil dari 5 usapan lantai, 4 usapan tempat tidur, 4 usapan dinding, 2 usapan selang $\mathrm{O}_{2}, 2$ usapan tabung $\mathrm{O}_{2}, 2$ usapan selang suction, 2 usapan tabung suction, dan 6 udara ruang.

Pada Tabel 2 dapat dilihat pertumbuhan bakteri pada media Nutrien Agar sebanyak 24 sampel dan pertumbuhan bakteri pada media Mac Conkey Agar sebanyak 17 sampel, sedangkan yang tidak ditemukan pertumbuhan bakteri pada Nutrient Agar sebanyak 3 sampel, dan pada Mac Conkey Agar 10 sampel.

Pada Tabel 3 dapat dilihat bakteri Gram negatif merupakan bakteri yang terbanyak $(87,5 \%)$ pada pewarnaan Gram.

Pada Tabel 4 dapat dilihat bakteri Enterobacter agglomerans dan Bacillus subtilis yang terbanyak, di mana masingmasing sebanyak 6 sampel (25\%). Pada Tabel 5 dapat dilihat pertumbuhan bakteri di dinding yaitu Bacillus subtilis sebanyak 1 sampel (100\%). 
Tabel 1. Sumber Pengambilan Sampel

\begin{tabular}{lc}
\hline Sampel & Jumlah \\
\hline Dinding & 4 \\
Lantai & 5 \\
Tempat Tidur & 4 \\
Selang $\mathrm{O}_{2}$ & 2 \\
Tabung $\mathrm{O}_{2}$ & 2 \\
Selang Suction & 2 \\
Tabung Suction & 2 \\
Udara & 6 \\
Total & $\mathbf{2 7}$ \\
\hline
\end{tabular}

Tabel 2. Pertumbuhan Bakteri dari Sampel

\begin{tabular}{lcc}
\hline Pertumbuhan & $\begin{array}{c}\text { Nutrient } \\
\text { Agar }\end{array}$ & $\begin{array}{c}\text { Mac Conkey } \\
\text { Agar }\end{array}$ \\
\hline $\begin{array}{l}\text { Ada pertumbuhan } \\
\text { Tidak ada }\end{array}$ & 24 & 17 \\
$\begin{array}{l}\text { pertumbuhan } \\
\text { Total }\end{array}$ & 3 & 10 \\
\hline
\end{tabular}

Tabel 3. Hasil Pewarnaan Gram

\begin{tabular}{lcc}
\hline \multicolumn{1}{c}{ Gram } & $\begin{array}{c}\text { Jumlah } \\
\text { Sampel }\end{array}$ & $\mathbf{\%}$ \\
\hline Bakteri Gram Positif & 1 & 4,167 \\
$\begin{array}{l}\text { Bakteri Gram } \\
\text { Negatif }\end{array}$ & 21 & 87,5 \\
$\begin{array}{l}\text { Bakteri Gram Positif } \\
\text { dan Negatif } \\
\text { Total }\end{array}$ & 2 & 8,333 \\
\hline
\end{tabular}

Tabel 4. Identifikasi Bakteri

\begin{tabular}{ccc}
\hline Bakteri & Jumlah & $\mathbf{\%}$ \\
\hline Enterobacter & 6 & 25 \\
agglomerans & & \\
Enterobacter cloacae & 4 & 16,7 \\
Serratia rubidaea & 1 & 4,1 \\
Klebsiella pneumonia & 1 & 4,1 \\
Kokus Gram negatif & 4 & 16,7 \\
Staphylococcus sp. & 2 & 8,4 \\
Bacillus subtilis & 6 & 25 \\
Total & $\mathbf{2 4}$ & $\mathbf{1 0 0}$ \\
\hline
\end{tabular}

Pada Tabel 6 dapat dilihat identifikasi bakteri di lantai terbanyak ialah kokus negatif sebanyak 3 sampel (60\%). Pada Tabel 7 dapat dilihat bakteri terbanyak yang tumbuh di tempat tidur yaitu Bacillus subtilis sebanyak 3 sampel (75\%).
Tabel 5. Distribusi Pertumbuhan Bakteri di Dinding

\begin{tabular}{ccc}
\hline Bakteri & Jumlah & $\mathbf{\%}$ \\
\hline Bacillus Subtilis & 1 & 100 \\
Total & $\mathbf{1}$ & $\mathbf{1 0 0}$ \\
\hline
\end{tabular}

Tabel 6. Distribusi Pertumbuhan Bakteri di Lantai

\begin{tabular}{ccc}
\hline Bakteri & Jumlah & $\mathbf{\%}$ \\
\hline Enterobacter & 2 & 50 \\
agglomerans & & \\
Staphylococcus sp. & 1 & 25 \\
Kokus Gram negatif & 1 & 25 \\
Total & $\mathbf{4}$ & $\mathbf{1 0 0}$ \\
\hline
\end{tabular}

Tabel 7. Distribusi Pertumbuhan Bakteri di Tempat Tidur

\begin{tabular}{ccc}
\hline Bakteri & Jumlah & $\mathbf{\%}$ \\
\hline Serratia rubidaea & 1 & 20 \\
Kokus Gram Negatif & 3 & 60 \\
Staphylococcus sp. & 1 & 20 \\
Total & $\mathbf{5}$ & $\mathbf{1 0 0}$ \\
\hline
\end{tabular}

Tabel 8. Distribusi Pertumbuhan Bakteri di Selang dan Tabung $\mathrm{O}_{2}$

\begin{tabular}{lcc}
\hline Bakteri & Jumlah & $\mathbf{\%}$ \\
\hline $\begin{array}{l}\text { Enterobacter } \\
\text { agglomerans }\end{array}$ & 1 & 25 \\
Bacillus subtilis & 3 & 75 \\
Total & $\mathbf{4}$ & $\mathbf{1 0 0}$ \\
\hline
\end{tabular}

Pada Tabel 8 dapat dilihat pertumbuhan bakteri terbanyak yang terdapat di selang dan tabung $\mathrm{O}_{2}$ yaitu Enterobacter agglomerans sebanyak 2 sampel (50\%).

Pada Tabel 9 dapat dilihat pertumbuhan bakteri di selang dan tabung suction yaitu Enterobacter agglomerans sebanyak 2 sampel (50\%) dan Enterobacter cloacae sebanyak 2 sampel (50\%).

Pada Tabel 10 dapat dilihat pertumbuhan bakteri di udara terbanyak yaitu Enterobacter cloacae dan Bacillus subtilis masing-masing sebanyak 2 sampel (33,3\%). 
Tabel 9. Distribusi Pertumbuhan Bakteri di Selang dan Tabung Suction

\begin{tabular}{ccc}
\hline Bakteri & Jumlah & $\mathbf{\%}$ \\
\hline $\begin{array}{c}\text { Enterobacter } \\
\text { agglomerans }\end{array}$ & 2 & 50 \\
$\begin{array}{c}\text { Enterobacter cloacae } \\
\text { Total }\end{array}$ & 2 & 50 \\
\hline
\end{tabular}

Tabel 10. Distribusi Pertumbuhan Bakteri di Udara

\begin{tabular}{ccc}
\hline Bakteri & Jumlah & $\mathbf{\%}$ \\
\hline $\begin{array}{c}\text { Enterobacter } \\
\text { cloacae }\end{array}$ & 2 & 33,3 \\
Enterobacter & 1 & 16,7 \\
agglomerans & & \\
Klebsiella & 1 & 16,7 \\
pneumonia & & \\
Bacillus subtilis & 2 & 33,3 \\
Total & $\mathbf{6}$ & $\mathbf{1 0 0}$ \\
\hline
\end{tabular}

\section{BAHASAN}

Hasil penelitian yang dilakukan di ruang ICU BLU RSUP Prof. dr. R. D. Kandou Manado, selama bulan November 2014 - Januari 2015 didapatkan 27 sampel dan terdapat beberapa jenis bakteri yang berpotensi menyebabkan infeksi nosokomial.

Pada penelitian ini, dari 27 sampel yang diperiksa, sebanyak 3 sampel tidak ada pertumbuhan dan 24 sampel terjadi pertumbuhan. Hasil koloni bakteri yang tumbuh selanjutnya dilakukan pewarnaan Gram dan kemudian dilakukan identifikasi dengan pemeriksaan secara mikroskopis dan dilanjutkan dengan uji biokimia. Pada uji biokimia ditemukan bakteri yang dapat menyebabkan infeksi nosokomial yaitu Enterobacter agglomerans sebanyak 6 sampel (25\%), Bacillus subtilis 5 sampel (20,8\%), Enterobacter cloacae 4 sampel (16,8\%), Kokus Gram negatif 4 sampel (16,8\%), Staphylococcus sp. 2 sampel (8,3\%), Serratia rubidaea 1 sampel $(4,1 \%)$ dan Klebsiella pneumonia 1 sampel $(4,1 \%)$

Enterobacter agglomerans atau sering disebut Pantoea agglomerans adalah anggota Enterobacteriacaea yang hidup di tanaman, tanah, dan air. Enterobacter agglomerans ditemukan sebanyak 6 sampel yang berasal dari tempat tidur sebanyak 1 sampel (25\%), selang dan tabung $\mathrm{O}_{2}$ sebanyak 2 sampel (50\%), selang dan tabung suction sebanyak 2 sampel (50\%), dan udara sebanyak 1 sampel (16,7\%). Hasil penelitian ini sama dengan penelitian yang dilakukan Liberto, dkk dengan judul Six cases of sepsis caused by Pantoea agglomerans in a teaching hospital yang menemukan Enterobacter agglomerans di ruang ICU. ${ }^{6}$

Bacillus subtilis umumnya ditemukan di udara, tanah, air, dan sayuran dan dapat menyebabkan meningitis, endokarditis, infeksi mata, dan lain-lain. ${ }^{7}$ Pada penelitian ini, Bacillus subtilis ditemukan sebanyak 6 sampel yang berasal dari dinding sebanyak 1 sampel (100\%), tempat tidur sebanyak 3 sampel (75\%), dan udara sebanyak 2 sampel (33,3\%). Hasil penelitian ini sama dengan yang didapatkan pada kultur bakteri udara ruang ICU RSUP dr. Wahidin Sudirohusodo Makassar tahun 2011 yang menemukan Bacillus subtilis sebanyak $10 \% .^{2}$

Enterobacter cloacae merupakan salah satu bakteri penyebab infeksi nosokomial seperti pneumonia, infeksi saluran kemih, infeksi luka, dan infeksi yang diperantarai alat. ${ }^{1} \quad$ Enterobacter cloacae ditemukan sebanyak 4 sampel yang berasal dari selang dan tabung suction sebanyak 2 sampel (50\%) dan udara sebanyak 2 sampel (33,3\%). Hasil penelitian ini sama dengan penelitian yang dilakukan oleh Bayani, dkk tahun 2013 dengan judul Drug resistance of Pseudomonas aeruginosa and Enterobacter cloacae isolated from ICU, Babol, Northern Iran yang menemukan dan menyelidiki pola resisten Enterobacter cloacae pada pasien yang dirawat di ICU. ${ }^{8}$

Kokus Gram negatif ditemukan sebanyak 4 sampel yang berasal dari lantai sebanyak 3 sampel (60\%), dan selang dan tabung $\mathrm{O}_{2}$ sebanyak 1 sampel (25\%). Berbeda dengan hasil penelitian yang dilakukan Oktarin tentang pola kuman pada dinding, lantai, dan udara di ICU RSUD dr. Moewardi Surakarta yang menemukan 
Bacillus sp, Staphylococcus, Morexella lacunata, Klebsiella pneumonia, E. coli dan Pseudomonas aerogenes di lantai. ${ }^{1}$

Staphylococcus sp. merupakan bakteri penyebab infeksi nosokomial tersering. ${ }^{1}$ Pada penelitian ini, Staphylococcus sp. ditemukan sebanyak 2 sampel yang berasal dari selang dan tabung $\mathrm{O}_{2}$ sebanyak 1 sampel (25\%) dan lantai sebanyak 1 sampel (25\%). Hasil penelitian ini sama dengan penelitian yang dilakukan oleh Juarez, dkk dengan judul The impact of hospitalacquired infection with multidrug-resistant bacteria in an oncology intensive care unit yang menemukan Staphylococcus aureus di ruang ICU. ${ }^{9}$

Serratia rubidaea ditemukan sebanyak 1 sampel yang berasal dari lantai (25\%). Hasil yang ditemukan ini berbeda dengan penelitian yang dilakukan oleh Khanna, dkk dengan judul Serratia marcescens a rare opportunistic nosocomial pathogen and measures to limit its spread in hospitalized patient yang menemukan Serratia marcescens di ICU. ${ }^{10}$

Klebsiella pneumonia merupakan salah satu penyebab infeksi nosokomial. Infeksi sering bersifat oportunis dan terjadi pada pasien rawat inap terutama di ICU. ${ }^{11}$ Pada penelitian ini, Klebsiella pneumonia hanya ditemukan hanya sebanyak 1 sampel yang berasal dari udara (16,7\%). Hasil penelitian ini sama dengan penelitian yang dilakukan oleh Naldu, dkk dengan judul A descriptive study of nosocomial infection in an adult intensive care unit in Fiji yang menemukan Klebsiella pneumonia di ruang ICU. ${ }^{12}$

\section{SIMPULAN}

1. Dari 27 sampel ditemukan 24 jenis bakteri, yang terbanyak ialah Enterobacter agglomerans dan Bacillus subtilis diikuti oleh Enterobacter cloacae, Staphylococcus sp., kokus Gram negative, Serratia rubidaea, dan Klebsiella pneumonia.

2. Dari 27 sampel ditemukan 6 spesies bakteri Enterobacter agglomerans dan Bacillus subtilis yang merupakan bakteri terbanyak.

\section{DAFTAR PUSTAKA}

1. Oktarin M. Angka dan Pola Kuman pada Dinding, Lantai, dan Udara di Ruang ICU RSUD Dr. Moewardi Surakarta. Fakultas Kedokteran Muhammadiyah Surakarta. 2013.

2. Noer SF. Pola Bakteri dan Resistensinya terhadap Antibiotik yang ditemukan pada Air dan Udara Ruang Instalasi Rawat Khusus RSUP Dr. Wahidin Sudirohusodo Makassar. Universitas Islam Makassar. 2011.

3. Nasution HL. Infeksi Nosokomial. Medan. 2012.

4. Nugraheni R, Suhartono, Wiharni S. Infeksi Nosokomial di RSUD Setjonegoro Kabupaten Wonosobo. 2012.

5. Zuhriyah L. Gambaran Bakteriologis Tangan Perawat. Malang. 2004.

6. Liberto M, Matera G, Puccio R, Russo T, Colosino E, Foca E. Six cases of sepsis caused by Pantoea agglomerans in teaching hospital. Italy. 2008.

7. Microbewiki. Bacillus subtilis. 2013 Maret. [cited at 2015 Jan 20]. Available from: http://microbewiki.kenyon.edu/index.ph p/Bacillus_subtilis

8. Bayani M, Siadati S, Rajabnia R, Taher A. Drug resistance of Pseudomonas aeruginosa and Enterobacter cloacae isolated from ICU, Babol, North Iran. 2013

9. Juarez C, Compte D, Jimenez P, Silva N, Hernandez S, Fernandez V. The impact of hospital-acquired infections with multidrud-resistant bacteria in an oncology intensive care unit. 2014.

10. Khanna A, Khanna M, Aggararwal A. Serratia marcescens- a rare opportunistic nosocomial pathogen and measeres to limit its spread in hospitalized patients. 2012.

11. Elliott $T$, Worthington $T$, Osman $H$, Gill M. Mikrobiologi Kedokteran dan Infeksi Edisi 4. Jakarta: Penerbit Buku Kedokteran EGC.

12. Naidu K, Nabose I, Ram S, Viney $K$, Graham S, Bisell K. A descriptive study of nosocomial infections in an adult intensive care unit in Fiji. 2011. 